\title{
Pelatihan Perakitan dan Pemograman Running Text bagi Warga Binaan Lapas Permisan Nusa Kambangan Kabupaten Cilacap
}

\author{
Arif Sumardiono $^{1 *}$, Erna Alimudin ${ }^{2}$, Hendi Purnata ${ }^{3}$, Saepul Rahmat $^{4}$, Zaenurohman $^{5}$ \\ 1,2 Program StudiTeknik Elektronika,Politeknik Negeri Cilacap, Indonesia \\ 3,4,5 Program Studi Teknik Elektronika, Politeknik Negeri Cilacap, Indonesia \\ Email: ${ }^{1}$ arifsumardiono@pnc.ac.id, ${ }^{2}$ ernaalimudin@pnc.ac.id, ${ }^{3}$ hendipurnata@pnc.ac.id, \\ ${ }^{4}$ saepulrahmat@gmail.com, ${ }^{4}$ zaenurohman@pnc.ac.id
}

\section{INFORMASI ARTIKEL}

\section{Data artikel:}

Naskah masuk, 6 Januari 2021

Direvisi, 27 Januari 2021

Diiterima, 6 Februari 2021

\section{Kata Kunci:}

Pelatihan,

Running Text,

Lembaga Pemasyarakatan,

Nusa Kambangan.

\begin{abstract}
ABSTRAK
Abstract- Penitentiary (LP) is a correctional facility in which there are assisted residents consisting of convicts. The social organization aims to ensure that its assisted residents are aware of the mistakes that have been made before and can improve themselves so that they do not fall into the same mistakes. In order to achieve this goal, the government has formulated the concept of structured guidance, training and empowerment in the field of religion or expertise for assisted residents so that they can have the ability after leaving the correctional institution. One of the well-known Penitentiary (LP) is in Cilacap Regency, precisely on the island of Nusa Kambangan. The penitentiary is called Lapas Permisan Nusa Kambangan. In this institution there are trainings for assisted residents so that after leaving the prison they can have business opportunities or get jobs to support their daily lives. One of them is training in making calligraphy in the form of figures, batik, etc. To make this happen. Therefore the Electrical Engineering Study Program will conduct training activities on how to assemble a dot matrix and its control devices to make running text and prayer time schedules. This activity is a positive alternative for the assisted residents, increasing the abilities and insights that will be used when they graduate as assisted residents or leave the Permisan Nusa Kambangan Prison. This training was held for 3 meetings with the preparation of modules and lesson plans to be adjusted.
\end{abstract}

Abstrak- Lembaga Pemasyarakatan (LP) adalah sebuah
lembaga pemasyarakatan yang didalamnya terdapat warga
binaan yang terdiri dari narapidana. Lembaga kemasyarakatan
bertujuan untuk agar warga binaannya dapat menyadari
kesalahan yang telah diperbuat sebelumnya dan dapat
memperbaiki diri sehingga tidak terjerumus kedalam kesalahan
yang sama. Demi mencapai tujuan tersebut maka pemerintah
merumuskan konsep pembinaan, pelatihan serta pemberdayaan
yang terstruktur di bidang agama atau pun keahlian bagi warga
binaan agar dapat mempunyai kemampuan setelah keluar dari
lembaga pemasyarakatan. Salah satu lembaga pemasyarakatn
yang terkenal terdapat di Kabupaten Cilacap tepatnya di Pulau
Nusa Kambangan. Lembaga Pemasyarakatan tersebut bernama
Lapas Permisan Nusa Kambangan. Di dalam lembaga ini
terdapat pelatihan - pelatihan bagi warga binaan agar setelah
keluar dari lembaga pemsyarakatan dapat memiliki peluang
usaha atau mendapatkan pekerjaan untuk bisa menghidupi
kehidupannya sehari - hari. Salah satunya terdapat pelatihan


pembuatan kaligrafi dalam bentuk figura, batik dll. Untuk mewujudkan hal tersebut. Oleh karena itu Program Studi Teknik Elektro akan melakukan kegiatan pelatihan cara merakit dot matrix beserta alat kontrolnya untuk membuat running text dan jadwal waktu sholat. Kegiatan tersebut menjadi alternatif kegiatan yang positif bagi warga binaan sehingga menambah kemampuan dan wawasan yang akan digunakan ketika lulus menjadi warga binaan atau keluar dari Lapas Permisan Nusa Kambangan. Pelatihan ini dilaksanakan selama 3 kali pertemuan dengan penyusunan modul dan rencana pembelajaran yang akan disesuaikan

\section{Korespondensi:}

\section{Arif Sumardiono}

Program Studi Teknik Elektronika, Politeknik Negeri Cilacap

J1. Dr. Soetomo No.1 Karangcengis, Sidakarya Cilacap, Indonesia

\section{PENDAHULUAN}

Kabupaten cilacap adalah salah satu daerah yang luas di propinsi jawa tengah, dengan batas sebelah selatan adalah samudra indonesia. Sebelah timur berbatasan dengan Kabupaten Kebumen. Sebelah utara berbatasan dengan kabupaten banyumas. Brebes dan Kuningaan Jawa Barat, serta sebelah barat berbatasan dengan Kota Banjar dan Kabupaten Ciamis [11]

Kabupaten Cilacap mempunyai salah satu Lembaga pemasyarakatan yang terkenal yaitu yang berada pada pulau Nusa Kambangan. Salah satu lapas yang terdapat pada Pulau Nusa Kambangan Yaitu Lembaga Pemasyarakatan Permisan. Lembaga tersebut adalah Lembaga Pemasyarakatan tertua yang ada sejak berdiri tahun 1908.Didalam Pulau Nusa Kambangan hanya dihuni oleh warga binaan dan pegawai Lapas beserta keluarganya. Dibawah pengawasan kementrian Kehakiman dan Pemerintah Kabupaten Cilacap. Warga Binaan serta petugas lapas harus ada ijin khusus dengan prosedur tertentu. Didalam pulau juga terdapat sekolah SD sebagai fasilitas bagi anak petugas lapas untuk bersekolah. Lapas Permisan Nusa Kambangan merupakan Lapas kelas medium yang didalamnya terdapat warga binaan yang sudah diperbolehkan untuk mengikuti suatu kegaiatan yang bermanfaat untuk menambah wawasan dan softkill dalam membuat produk seperti batik, otomotif, kaligrafi. Berdasarkan diskusi dengan ketua Lapas permisan yaitu Bapak Sopian mengatakan jumlah Warga Binaan yang mencapai 476 membuat kegiatan kegiatan tersebut terasa kurang untuk Warga Binaan Lapas Permisan Nusa kambangan, sehingga diperlukan suatu kegaiatan baru yang dapat menampung Warga Binaan untuk menambah wawasan dan kemampuannya, Kepala Lapas Nusa Kambangan meminta agar ada kegiatan - kegiatan yang berhubungan dengan dunia elektronika, sehingga merupakan peluang bagi Teknik Elektronika untuk memberikan pengabdian kepada masyarakat untuk melatih cara merakit dan memprogram runing text dan jadwal waktu sholat agar menjadi sebuah kegiatan baru sekaligus menjadi produk baru Lapas Permisan Nusa Kambangan, oleh sebab itu. diperlukan suatu pelatihan khusus tentang pengunaan alat elektronika tersebut oleh individu - individu yang kompeten dibidang tersebut. individu individu tersebut akan memberikan pengarahan, bimbingan serta pelatihan pengenalan komponen elektronika yang akan diaplikasikan menjadi jam digital, jadwal 
waktu sholat, dan teks berjalan sehingga diharapkan kegiatan tersebut terjadi secara berkesinambungan

\section{METODE PELAKSANAAN}

Metode Kegiatan yang akan dilakukan pada pengabdian masyarakat adalah dengan memberikan pelatihan, pengarahan dan bimbingan pengenalan komponen elektronika sederhana bagi Warga Binaan. Pemberian materi dilakukan secara bertahap yaitu dengan konsep sebagai berikut :

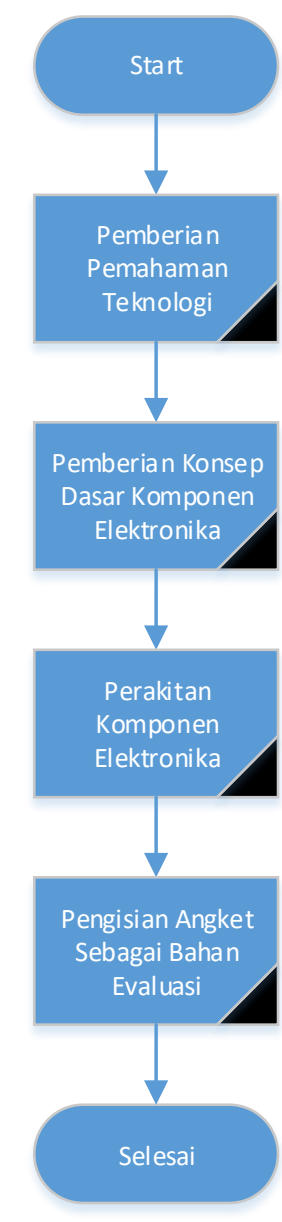

Gambar 1. Flowchart Kegiatan

\section{a. Pemahaman Teknologi}

Dalam Tahap ini warga binaan diperkenalkan dulu secara garis besar apa yang dimaksud dengan teknologi, peran teknologi bagi kehidupan manusia, serta prinsip - prinsip dasar tentang materi - materi yang akan dikenalkan kepada Warga Binaan.

\section{b. Pemahaman Konsep Dasar Komponen Elektronika}

Dalam Tahap ini Warga Binaan diperkenalkan dengan komponen elektronika yang dibutuhkan. Seperti bentuknya, karakteristik penggunaanya dengan bahasa yang mudah dimengerti oleh warga binaan tentunya. Komponen - komponen elektronika yang akan diperkenalkan dalam pengabdian masyarakat sebagai berikut :

\section{1) Display Led Matrik P10}

Display Led Matrik P10 merupakan sebuah display yang dapat menampikan text berjalan ataupun jadwal sholat sesuai dengan program yang dimasukan dalam mikrokontroler.

\section{2) Power Suplay 5 Volt}

Power Suplay ini sebagi sumber untuk diberikan ke mikrokontroler dan kontroler WD60 dan juga suplay tambahan untuk dot matriks P10.

3) Modul RTC DS3231

RTC sebagai real time clock, buzzer sebagai alarm, dan Eeprom AT24C32 sebagai memori eksternal. Eeprom AT24C32 digunakan untuk menyimpan data base jadwal waktu shalat selama 1 tahun. [5]

\section{4) Kabel Jumper}

Kabel jumper disini digunakan untuk menghubgkan antara komponen komponen yang diperlukan dengan mikrokontroler.

5) Kabel Data LED Matrik

Kabel data ini untuk menyambungkan dan mengirimkan data dari mikrokontroler ke Led Matrik P10, tetapi juga bisa menyambungkan jika ada beberapa panel Led matrik P10.

\section{6) Kontroler WD60}

Merupakan modul yang digunakan untuk mensetting program pada Led Matrik P10.

7) Flashdisk

Sebagai media penghantar data yang akan dihubungkan ke kontroler TFS6U yang 
didalamnya terdapat program running text. Flashdisk digunakan ketika setting program belum menggunakan bluetooth.

\section{c. Perakitan Komponen Elektronika}

Setelah pengenalan konsep dasar elektronika, selanjutnya adalah proses perakitan dot matrik dengan kontrolernya. Disini warga binaan diharapkan merakit langsung dengan tangannya sendiri atau langsung dipraktikan sehingga diharapkan lebih mudah dalam memahami perakitan komponen elektronika tersebut.

\section{d. Pengisian Angket Sebagai Evaluasi Pelaksanaan PKM}

Pada pelaksanaan PKM di Lapas Permisan Nusa Kambangan setelah dilakukan pelatihan pembuatan running text maka para warga binaan diberikan angket untk diisi sebagai bahan evaluasi dari kegiatan PKM. Angket di bagi menjadi dua bagian yaitu mengenai motivasi warga binaan dalam mengikuti pelatihan, serta yang kedua yaitu angket tentang kepuasan warga binaan terhadap pelaksanaan pelatihan running text.

\section{HASIL DAN PEMBAHASAN}

Kegiatan pengabdian masyarakat ini dilakukan dengan melakukan pelatihan secara langsung terhadap Warga Binaan di Lembaga Pemasyarakatan Permisan Nusa Kambangan. Kegiatan pengabdian kepada masyarakat ini dimulai dengan cara negosiasi dan komunikasi antar pelaksana kegiatan dengan pegawai Lapas Permisan Nusa Kambangan. Negosiasi tersebut dilakukan karena ada nya beberapa protokol yang harus dilaksanakan dan dipatuhi baik bagi Para Pegawai, Warga binaan maupun pelaksana pengabdian dikarenakan adanya masa pandemi corona yang terjadi saat ini yaitu pada tahun 2020 .

Pada kegiatan hari pertama untuk sampai dipulau Nusa Kambangan para pelaksana pengabdian pada masyarakat harus melalui protokol pemeriksaan pada Pos Penyebrangan untuk diperiksa barang bawaan dan dilihat surat ijin perjalanan dinas yang sudah dibuatkan oleh Lembaga Pemsyarakatan sehingga tidak semua orang dapat keluar masuk ke Pulau Nusa Kambangan kecuali Warga Nusa Kambangan yang memiliki ID khusus. Ketika sudah sampai Pelabuhan Sodong maka akan ada perjalanan yang memakan waktu 30 menit menggunakan kendaraan bermotor untuk sampai Ke Lapas Permisan Nusa Kambangan sehingga di total sekitar 40 menit dari penyebrangan untuk sampai ke Lapas Permisan Nusa Kambangan.

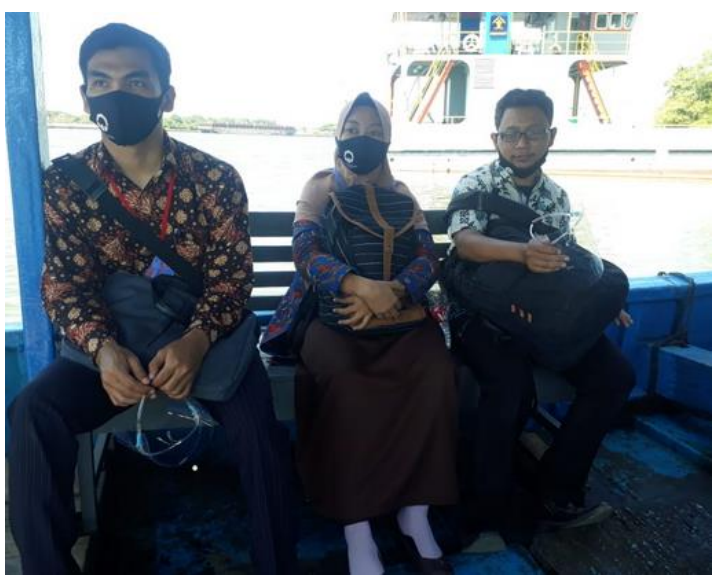

Gambar 2 . Perjalanan Menggunakan Perahu Ke Nusa Kambangan

Warga binaan yang hadir pada kegiatan hari pertama yaitu 21 orang. Kegiatan hari pertama diisi dengan materi yaitu memperkenalkan komponen - komponen elektronika yang akan digunakan untuk membentuk Running Text dan jadwal waktu sholat.

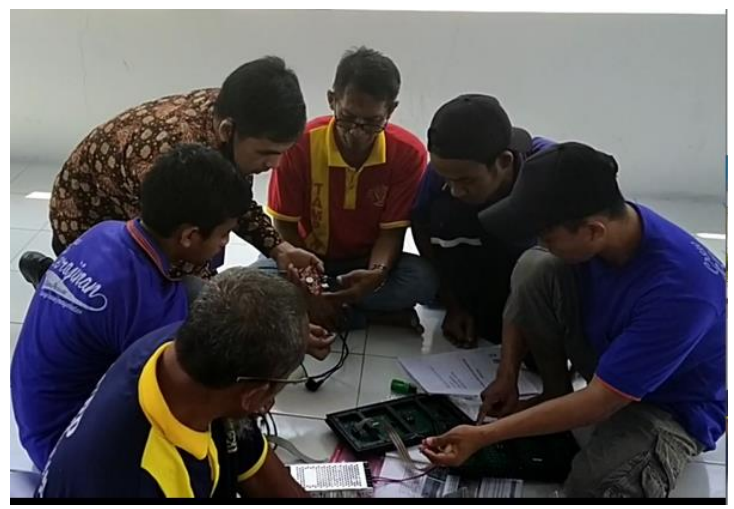

Gambar 3. Pengenalan Komponen Elektronika kepada Warga Binaan 
Terlihat pada gambar adanya antusias baik dari Pegawai Lapas Permisan Nusa Kambangan dan Warga Binaan untuk mengetahui komponen eletronika apa saja yang digunakan dan bagaiman fungsi dari komponen tersebut sehingga dapat membuat sebuah Running Text.

Setelah dilakukan pengenalan tentang komponen elektronika, maka tahap selanjutnya yaitu proses perakitan running text secara serial sekaligus memprogram running text yang di bimbing oleh instrukture atau tim pelaksana pengabdian kepada masyarakat yang dapat dilihat pada gambar 4

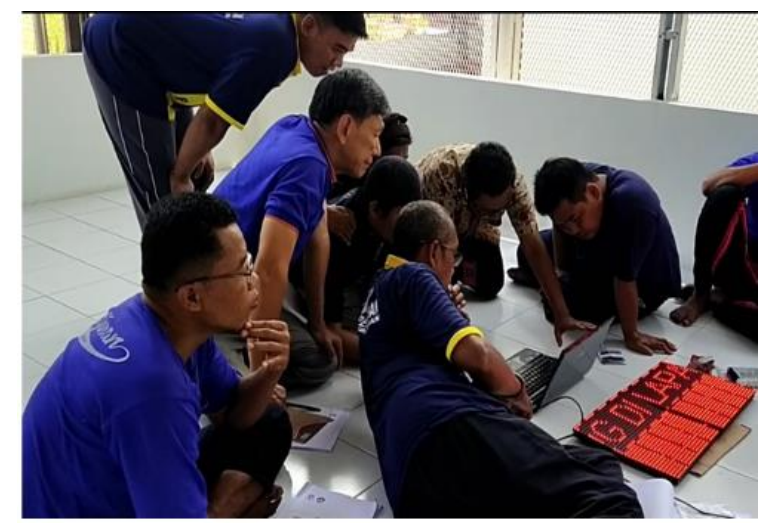

Gambar 4. Pemograman dan Perakitan Running Text

Pada hari ketiga kegiatan dilakukan dengan pengenalan kontroler jadwal waktu sholat (JWS) yang bisa disetting menggunakan handphone. Setelah pengenalan JWS selanjutnya adalah pengenalan frame serta perakitan frame running text untuk mempercantik tampilan running text.

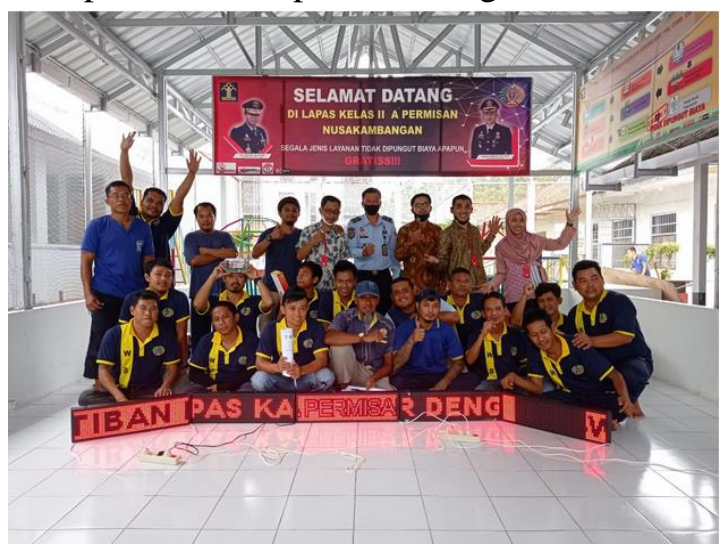

Gambar 5. Hasil Perakitan Running Text dan sudah di Frame
Pada pengabdian ini disebarkan angket yang harus diisi warga binaan untuk mengetahui respon warga binaan terhadap pelatihan ini serta menjadi evaluasi bagi tim pelaksana pengabdian masyarakat Teknik Elektronika Politeknik Negeri Cilacap dari kegiatan tersebut.

Tabel 1. Angket Motivasi Warga Binaan

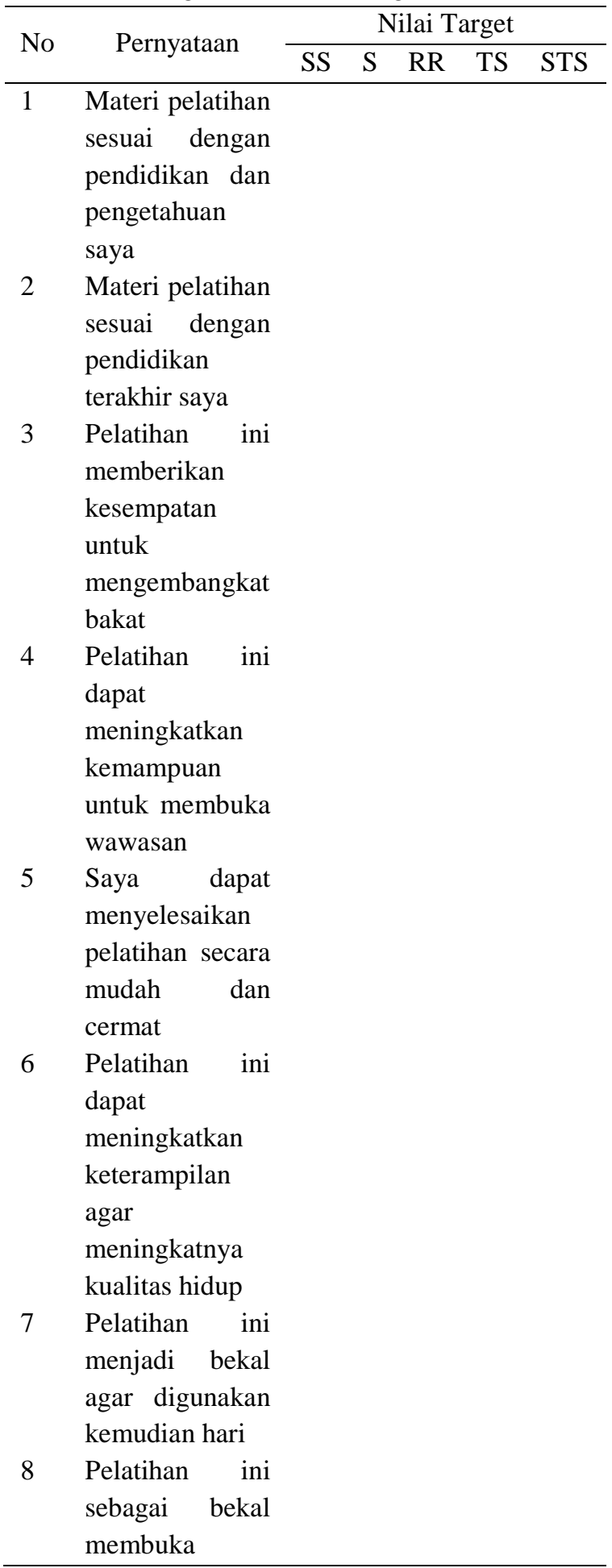




\begin{tabular}{ll}
\hline & peluang \\
menjadi & \\
& wirausaha \\
$9 \quad$ & Pelatihan ini \\
menambah \\
semangat dalam \\
wawasan dunia \\
elektronika \\
\hline
\end{tabular}

Tabel 2. Angket tanggapan terhadap pelatihan

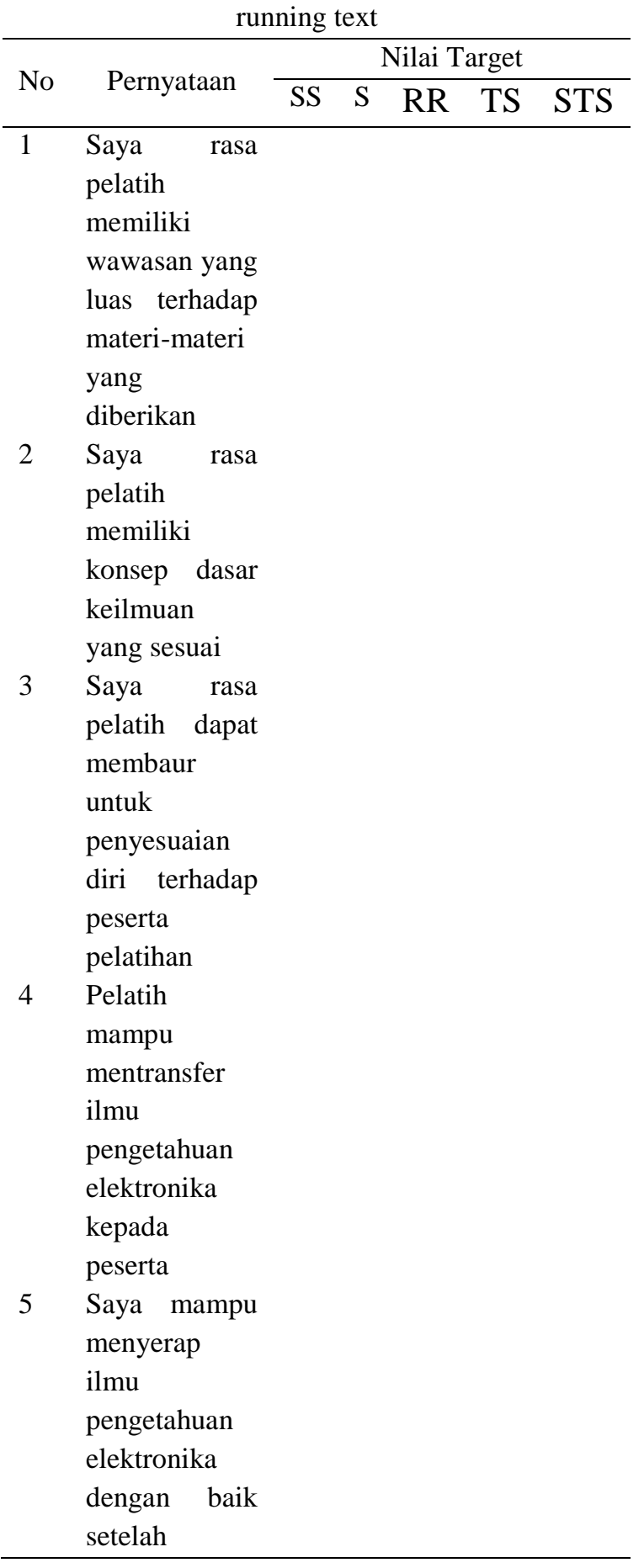

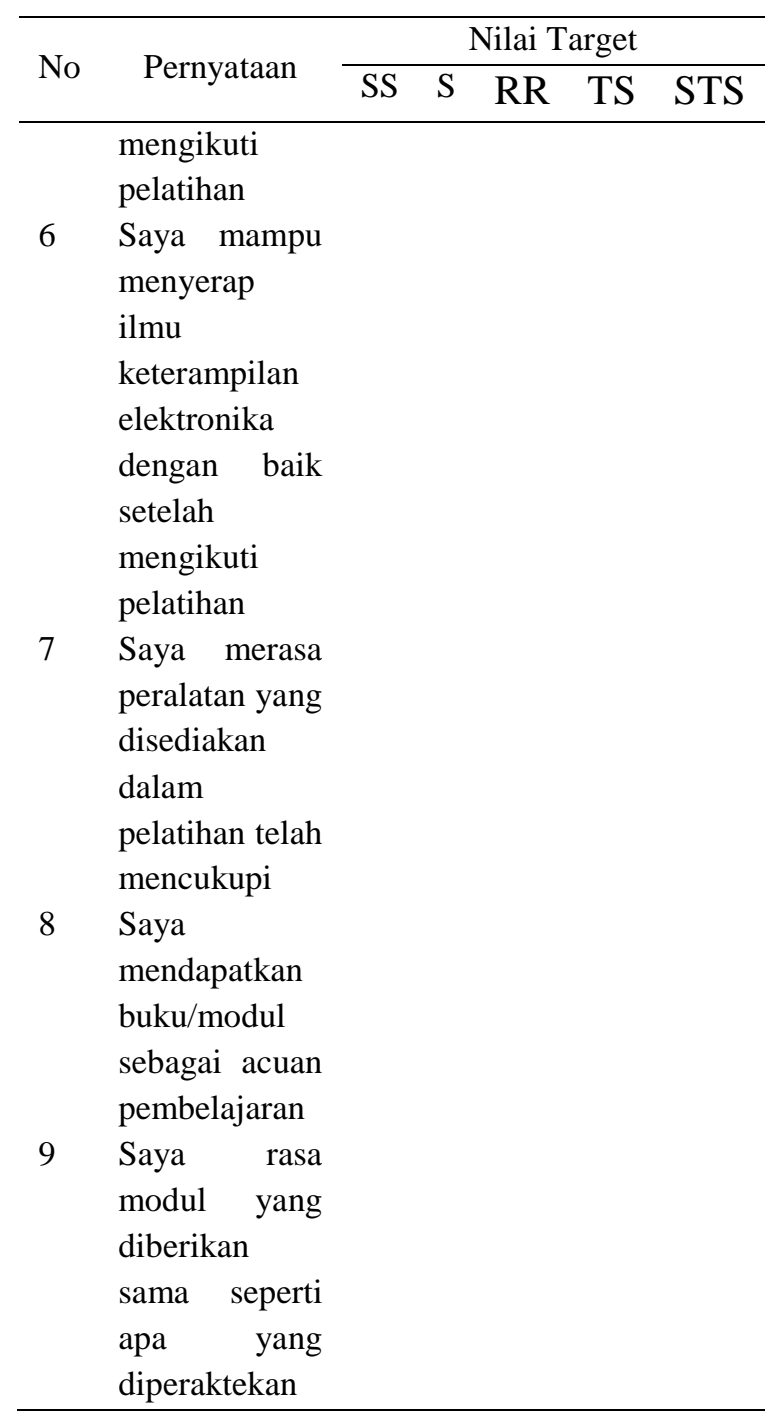

Hasil angket motivasi para warga binaan dalam mengikuti pelatihan adalah sebagai berikut :

a. Pelatihan ini memberikan kesempatan untuk mengembangkan bakat

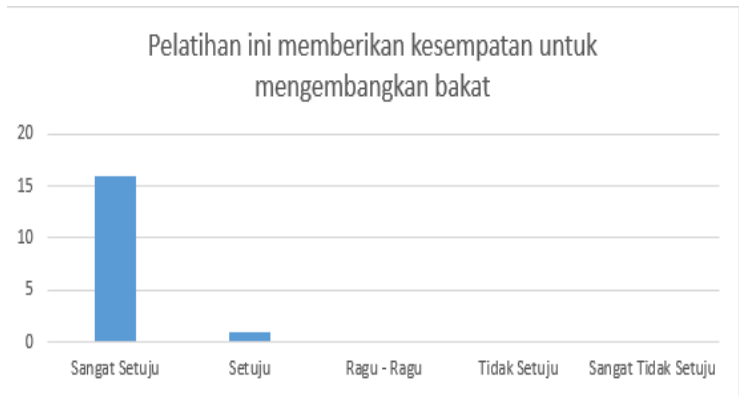

Gambar 6. Respon terhadap apakah Pelatihan ini memberikan kesempatan untuk mengembangkan bakat 
Pada grafik tersebut dapat dilihat bahwa warga binaan menilai bahwa pelatihan ini memberikan kesempatan bagi warga binaan untuk mengembangkan bakat. Hal ini dilihat pada grafik bahwa sebagian besar sangat setuju dan setuju dalam pengisian angket.

b. Pelatihan ini dapat meningkatkan kemampuan untuk membuka wawasan

Pelatihan ini dapat meningkatkan kemampuan untuk membuka wawasan

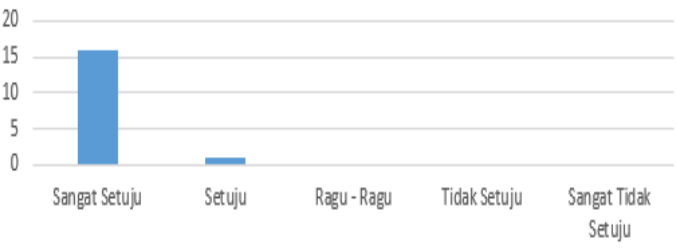

Gambar 7. Respon terhadap apakah Pelatihan ini dapat meningkatkan kemampuan untuk membuka wawasan

Pada data tersebut disimpulkan bahwa warga binaan menilai pelatihan ini sudah menambah wawasan bagi warga binaan terutama tentang pembuatan running text. Hal ini dilihat pada grafik bahwa sebagian besar sangat setuju dan setuju dalam pengisian angket.

c. Saya dapat menyelesaikan pelatihan secara mudah dan cermat

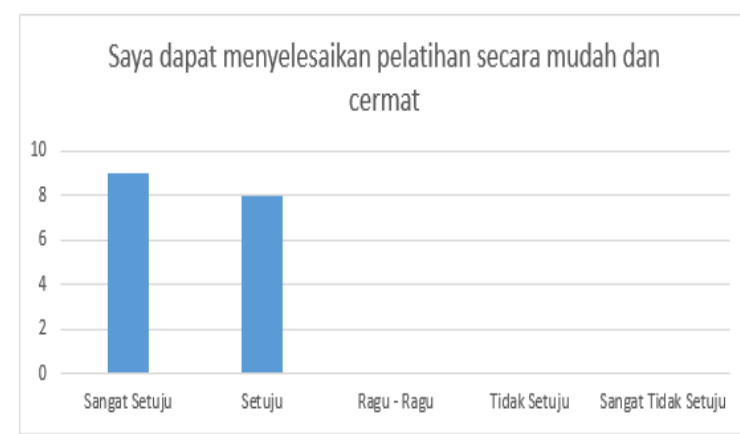

Gambar 8. Saya dapat menyelesaikan pelatihan secara mudah dan cermat

Berdasarkan data tersebut bahwa warga binaan dapat mengikuti kegiatan pelatihan dengan mudah dan cermat dikarenakan adanya modul, alat praktik dan mentor. d. Pelatihan ini menjadi bekal agar digunakan kemudian hari

Pelatihan ini menjadi bekal agar digunakan kemudian

hari

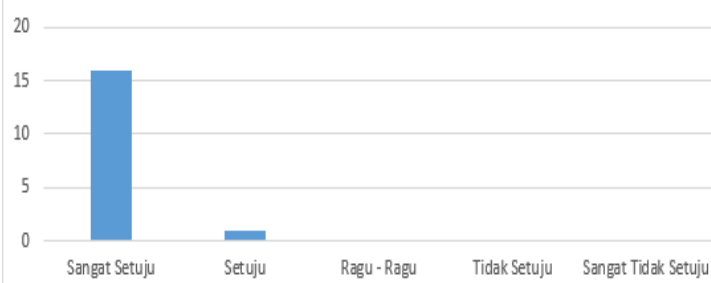

Gambar 9. Respon terhadap apakah Pelatihan ini menjadi bekal agar digunakan kemudian hari

Pada data tersebut dapat dilihat bahwa respon terhadap harapan sebagai bekal yang bisa digunakan kemudian hari sangat baik dan setuju Hasil angket tanggapan terhadap pelaksanaan pelatihan para warga binaan dalam mengikuti pelatihan adalah sebagai berikut :

a. Saya rasa pelatih memiliki wawasan yang luas terhadap materi - materi yang diberikan

Saya rasa pelatih memiliki wawasan yang luas terhadap materi - materi yang diberikan
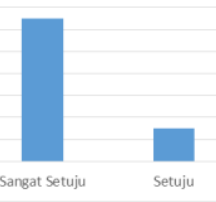

Gambar 10. Respon terhadap pelaksanaan pelatihan

Berdasarkan pada gambar 10 menunjukan bahwa warga binaan merasa setuju dengan pelatihan ini dikarenakan adanya transfer pengetahuan oleh para pembimbing pelatihan

b. Saya rasa pelatih dapat membaur untuk penyesuaian diri terhadap peserta pelatihan

Saya rasa pelatih dapat membaur untuk penyesuaian diri terhadap peserta pelatihan

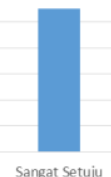
Ragu-Ragu Tidak Setuju Sangat Tidak Setuiu 
Gambar 11. Respon terhadap Pelaksana PKM dalam membaur dengan warga binaan

Berdasarkan gambar 11 menunjukan bahwa para pemibimbing dalam pelatihan dapat membaur dengan warga binaan dengan baik

c. Saya mampu menyerap ilmu pengetahuan elektronika dengan baik setelah mengikuti pelatihan

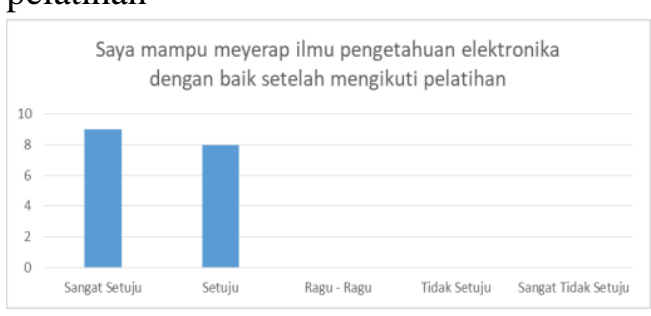

Gambar 12. Respon terhadap penyerapan dan pemahaman materi oleh warga binaan

Berdasarkan gambar 12 menunjukan bahwa peserta pelatihan sudah dapat menyerap apa yang diberikan saat running text. Hal ini juga didukung hasil pengamatan dilapangan bahwa para warga binaan pada hari kedua sudah bisa memprogram dan merakit running text dalam waktu yang singkat.

d. Saya merasa peralatan yang disediakan dalam pelatihan telah mencukupi

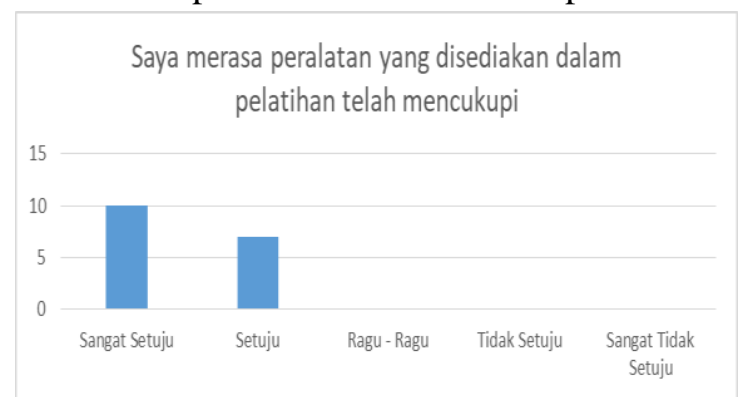

Gambar 13. Respon terhadap fasilitas pelatihan yang diberikan

Pada gambar 13 menunjukan bahwa warga binaan merasa bahwa modul dan alat - alat untuk membuat running text sudah sangat baik dan lengkap sehingga pelatihan dapat berjalan dengan lancar.

\section{KESIMPULAN}

Pelatihan di Lapas Permisan Nusa Kambangan sudah berjalan dengan baik walaupun dalam keadaan terjadinya wabah virus corona sehingga harus tetap memperhatikan protokol - protokol kesehatan dalam melaksanakan kegiatan pelatihan tersebut. Hasil dari kegiatan pengabdian masyarakat tersebut dapat terlihat bahwa para warga binaan Lapas Permisan Nusa Kambangan dapat menerima masukan materi materi pelatihan dengan baik dibuktikan pada hari kedua dapat merakit dan memprogram running text dengan waktu yang singkat. Berdasarkan hasil dari angket bahwa warga binaan sangat tertarik dengan pelatihan running text dan warga binaan dapat memahami apa yang sudah diajarkan baik dari materi ataupun praktiknya.

Kedepannya diharapakan wabah virus corona dapat segera selesai sehingga dapat dilakukan pelatihan yang lebih optimal yaitu pengenalan - pengenalan komponen elektronika yang lebih dalam lagi agar ketika terjadi permsalahan pada sistem elektronikadapat diperbaiki sendiri oleh warga binaan.

\section{UCAPAN TERIMA KASIH}

Terima kasih kepada P3M Politeknik Negeri Cilacap yang telah memberikan dukungan baik secara moril dan materil, serta Ketua Lapas Permisan bapak sopian yang telah mengijinkan dan memberika dukungan sehingga kegiatan pelatihan perakitan dan pemograman runnning text dapat berjalan dengan baik dan para pelaksana pengabdian mendapatkan pembelajaran dari sisi lain Lembaga Pemasyarakatan.

\section{DAFTAR PUSTAKA}

Ayu Lestari (2016). Keterampilan Membatik Bagi Narapidana di Lembaga Pemasyarakatan Klas IIB Blitar. Jurnal Tata Busana, 5(1).

Juliani, R., Utari, S., \& Saepuzaman, D. 
(2017). Rekonstruksi rancangan rencana pelaksanaan pembelajaran (rpp) melalui analisis kesulitan literasi sains peserta didik sekolah menengah pertama pada topik listrik dinamis. Jurnal Penelitian Pendidikan Matematika dan Sains, 1(1).

Kanoi, Y. H., Abdussamad, S., \& Dali, S. W. (2019). Perancangan Jam Digital Waktu Sholat Menggunakan Arduino Uno. Jambura Journal of Electrical and Electronics Engineering, 1(2).

Riyono, J. (2017), Sistem Informasi Pemesanan Lapangan Futsal Berbasis Aplikasi Android Dengan Metode Transaksi Menggunakan Kartu Rfid, Universitas Teknologi Yogyakarta.

Simanjuntak, I. U., \& Suhendar, A. (2018). Rancang Bangun Running Text P10 16x32 Berbasis Arduino Uno Dengan Komunikasi Sms (Short Message Service). Jurnal Ilmiah Teknologi Infomasi Terapan, 4(2).

Kandou, E. E. (2013). Pengaruh Pelatihan Dan Pengembangan Karyawan Terhadap Produktivitas Kerja Karyawan (Studi Pada PT. Air Manado). ACTA DIURNA KOMUNIKASI, 2(3).

Lolowang, M. G., Adolfina, A., \& Lumintang,
G. (2016). Pengaruh Pelatihan dan Pengembangan Sumber Daya Manusia terhadap Kinerja Karyawan pada Pt. Berlian Kharisma Pasifik Manado. Jurnal EMBA: Jurnal Riset Ekonomi, Manajemen, Bisnis dan Akuntansi, 4(2).

Wulandari, S. (2016). Efektifitas Sistem Pembinaan Narapidana Di Lembaga Pemasyarakatan Terhadap Tujuan Pemidanaan. Hukum Dan Dinamika Masyarakat, 9(2).

Cahyono, A. S. (2014). Pemberdayaan Dan Pengembangan Keterampilan Warga Binaan Di Lembaga Pemasyarakatan Kelas II B Tulugagung. Jurnal BONOROWO, 2(1), 1-10.

Zainuri, A., Wibawa, U., \& Maulana, E. (2016). Implementasi Bluetooth HC-05 untuk Memperbarui Informasi Pada Perangkat Running Text Berbasis Android. Jurnal EECCIS, 9(2), 163-167 Kuang, P., Cao, W. N., \& Liu, Z. G. (2014, December). Design of dynamic screen system based on MCU. In 2014 11th International Computer Conference on Wavelet Actiev Media Technology and Information Processing (ICCWAMTIP) (pp. 468-470). IEEE. 